\title{
Erratum to: Patterns of coccolithophore pigment change under global acidification conditions based on in-situ observations at BATS site between July 1990-Dec 2008
}

\author{
Jianhai LV ${ }^{1,4}$, Yaoqiu KUANG ${ }^{1}$, Hui ZHAO (ه) $)^{2,3}$, Andreas ANDERSSON ${ }^{2}$ \\ 1 Guangzhou Institute of Geochemistry, Chinese Academy of Sciences, Guangzhou 510640, China \\ 2 Bermuda Institute of Ocean Sciences, Ferry Reach, St. Georges GE-01, Bermuda \\ 3 Guangdong Ocean University, Zhanjiang 524088, China \\ 4 Marine and Fishery Environment Monitoring Center of Guangzhou, Guangzhou 510235, China
}

(C) Higher Education Press and Springer-Verlag Berlin Heidelberg 2017

\section{Erratum to: Front. Earth Sci. \\ DOI 10.1007/s11707-015-0503-x}

The authors requested that an Erratum be published containing a correction to the authors lists, text, acknowledgements.

1) Dr. Andreas Andersson was unknowingly and incorrectly included as a co-author on this paper. He did not see or contribute to this manuscript before submission and does not endorse the results and findings of this study. Dr. Andersson is not a co-author. The paper should be cited as: "Lv J, Kuang Y, Zhao H (2017). Patterns of coccolithophore pigment change under global acidification conditions based on in-situ observations at BATS site between July 1990-Dec 2008. Frontiers of Earth Science, 11(2): 297-307”.

The authors list and their affiliations are changed as follows (Andreas ANDERSSON is removed) :

\author{
Jianhai LV ${ }^{1,2}$, Yaoqiu KUANG ${ }^{2}$, Hui ZHAO $(\bowtie)^{3}$ \\ 1 Marine and Fishery Environment Monitoring Center of Guangzhou, Guangzhou 510235, China \\ 2 Guangzhou Institute of Geochemistry, Chinese Academy of Sciences, Guangzhou 510640, China \\ 3 Guangdong Ocean University, Zhanjiang 524088, China
}

2) In the article

(1) Before the first sentence of the Section '2.3.1 Time series data and power spectral analysis' on page 3, added "The parameters of $\mathrm{pH}, \mathrm{HCO}_{3}{ }^{-}, \mathrm{CO}_{3}{ }^{2-}$, omega were calculated with the help of a user-friendly seawater carbon calculator for windows (available at http://cdiac.ornl.gov/oceans/co2rprt.html). And the latest dissociation constants were used in the above calculation."

(2) In the list of references on page 11, replaced "Michaels A F (1995). Ocean time series research near Bermuda: the Hydrostation S time series and the Bermuda Atlantic time series study (BATS). In: Powell T M, Steele J H, eds. Ecological Time Series. New York: Chapman and Hall, 181-208" with "Lomas M W, Bates N R, Johnson R J, Knap A H, Steinberg D K, Carlson C A (2013). Two decades and counting: 24-years of sustained open ocean biogeochemical measurements in the Sargasso Sea. Deep Sea Res Part II Top Stud Oceanogr, 93: 16-32".

E-mail: chaohui@scsio.ac.cn

\footnotetext{
${ }^{*}$ The online version of the original article can be found at http://dx.doi.org/10.1007/s11707-015-0503-x
} 
(3) Replaced "Michaels, 1995" with "Lomas et al, 2013" throughout the article.

(4) On lines 3-4 of page 10 from top, "influencing oceans", is changed to "influencing upper oceans including diverse meso-scale eddies and wind stress curls (McGillicuddy et al., 1998, 1999, 2007; Siegel et al., 2011)".

(5) In the list of "References" of page 11, after the reference "Marshall H (1968) ... 370-376", Added the following 3 references in sequence:

McGillicuddy D J, Anderson L A, Bates N R, Bibby T, Buesseler K O, Carlson C A, Hansell D A (2007). Eddy/wind interactions stimulate extraordinary mid-ocean plankton blooms. Science, 316(5827): 1021-1026

McGillicuddy D J, Robinson A R, Siegel D A, Jannasch H W, Johnson R, Dickey T D, McNeil J, Michaels A F, Knap A H (1998). Influence of mesoscale eddies on new production in the Sargasso Sea. Nature, 394: 263-266

McGillicuddy D J, Johnson R J, Siegel D A, Michaels A F, Bates N, Knap A H (1999). Mesoscale variability of ocean biogeochemistry in the Sargasso Sea. J Geophys Res, 104: 13381-13394

(6) In the list of "References" of page 11, after the reference "Riebesell U ... 365-367", Added the reference "Siegel D A, Peterson P, McGillicuddy D J, Maritorena S, Nelson N B (2011). Biooptical footprints created by mesoscale eddies in the Sargasso Sea. Geophys Res Lett, 38: L13608”.

(7) Acknowledgments are revised as follows: "Hui ZHAO would like to thank the Nippon foundation, the Programme for Observation of the Global Ocean, Bermuda Institute of Ocean Science, Dr. Nicholas R. Bates, Dr. Michael W. Lomas, Dr. Rod Johnson, Dr. Tony Knap, Dr. Gerald Plumley, and Jerome Aucan. The success of the BATS program to date is the result of the hard work and dedication of many scientists and technicians. We acknowledge them for providing support and scientific guidance, and for carrying out the initial analyses or processing of some of the core measurements. The study would not have been finished without the careful guidance of Dr. Andreas Andersson and the outstanding support of the captains, crews, and marine technicians of the research vessels." 